\title{
The Unconscious is Structured like an Archive:"Epic" Politics and Postmodernity in Indonesian Cinema Dag Yngvesson
}

Looking beyond an understanding of the modern world as mainly determined by the development of European and American capitalism, this article closely reads the popular 1970 Indonesian film Bernafas dalam Lumpur (Breathing in Mud, Tourino Djunaidy). The film is taken as an archival document of the absorption of global, and especially local stylistic and narrative modes into Indonesian cinema at a key historical moment: the period following the mass violence of 1965-66 during the rise of dictator Suharto. I argue that Bernafas and other contemporary Indonesian films anticipate the "postmodern" engagement with past events and dramatic forms that Fredric Jameson and other critics see inflecting American and European cinema, particularly after the mid 1970s. As I show, Bernafas dalam Lumpur thus appropriates, adapts, and redeploys the structures of past and present media not as a follower of Western postmodernism, but as knowing beneficiary of a historically established political tactic. In the context of its production and reception post-1965, the film's "epic" sense of time and form has an uncanny, archival function, confronting audiences with spectres of the disturbing, senselessly violent events that had been sealed from public discussion or memorialization by the censorious policies of the emergent Suharto state.

Keywords: world cinema, postmodernism, Indonesia, New Order, archives

Turino Djunaidy's Bernafas dalam Lumpur [Breathing in Mud], a 1970 Indonesian film, tracks the fate of a poor woman from a farming village who comes to Jakarta, then as now Indonesia's teeming megalopolis capital, to search for her missing husband. The woman's chance encounters with several men from a variety of backgrounds, all of whom exploit her sexually or economically without a second thought, become turning points that shape the course of her short life. This paper argues that the woman's apparently random encounters throughout the movie in fact indicate the presence of an otherwise unacknowledged source of power and control: the political, historical "mud" in which the characters, and presumably all people, are immersed, with varying degrees of awareness. As this paper will show, this accumulated substance, consisting of the inscriptions, impressions, and "secretions" produced by a society over time can be compared to an archive from which a critical and politically potent understanding may potentially emerge. 
In a number of ways, Djunaidy's conspiratorial mire evokes the "absent, unrepresentable totality" (1992b, p. 10), that for Fredric Jameson haunts and structures the worlds of mid-1970s and 1980s North American detective thrillers like Alan Pakula's Parallax View (1974), Sydney Pollack's Three Days of the Condor (1975), and Brian De Palma's Blow Out (1981). Not unlike Djunaidy's pervasive mud, which surreptitiously connects Indonesian villages to cities and from there moves people, money, and ideas to and from urban centers abroad, Jameson's totality is an omnipresent yet unseen force that exceeds the control of individuals. It functions like a geopolitical unconscious, at once "an economic system on the scale of the globe itself," and "a potentially infinite network" (1992b, p. 9). Yet to make a comparison between the philosophically rich but simultaneously lowbrow approach of Djunaidy's cinema in the early 1970s, and the similar mixtures of elements deployed by directors like Pollack and De Palma from the mid-1970s to the 1980s, is to disrupt Jameson's broadly influential mapping of historical development, which holds that so-called Third World nations necessarily trail Western ones in the emergence of such postmodern modes of thought and expression. What then to make of the similarities of a film like Djunaidy's to those that were shaped by more "advanced" milieus? What are the formal conditions of possibility that have produced the particular perspective and style of Bernafas dalam Lumpur and other Indonesian films before and after it?

Endeavoring to look beyond a limited understanding of the modern world as mainly determined by the development of European and American capitalism, in this paper I trace the historical roots of Bernafas dalam Lumpur's local stylistic and narrative modes-elements that necessarily constitute a global perspective from a certain geopolitical standpoint. In so doing, I search the structures of local languages and of earlier films, literature, and other screen-based media such as wayang (shadow play) for an "archive" that contains similar basic approaches to time, individual agency, political intervention, and audience engagement, among other things. In the case of Bernafas, its modes and their roots are of interest not only because of their apparent similarity to Western postmodernist approaches but also because of the way they reflect a local historical penchant for combining popular entertainment with political intervention-what David Hanan (2009) has also described as a "tradition of political satire" (p. 14).

While the political value of many classic film nasional of the Sukarno era (1949-1965) is generally well-recognized, like Hanan $(2009)^{1} \mathrm{I}$ am also interested in how critique was embedded during the far more repressive Suharto era (1966-1998) in less overtly serious works such as slapstick comedies, and in films that were often categorized as cheap, sex-saturated 
melodramas, like Bernafas dalam Lumpur. A huge hit that was produced in the aftermath of the violent rise of dictator Suharto, Bernafas touched off a wave of similarly structured popular films about prostitutes, many of which packed a surprisingly powerful and critically underappreciated political punch. ${ }^{2}$ But before embarking on an analysis of Bernafas and its traditional/ postmodern intervention into Indonesian politics, I begin, in the interest of comparison, with a detailed background of what is generally labelled postmodern cinema in the United States and Europe.

\section{The Kane-ing of Time: \\ Postmodernization and the Development of Western Cinema}

For Jameson (1992a, 1992b), Gilles Deleuze (1989), and Slavoj Žižek (1991), ${ }^{3}$ only after Western cinema began to challenge its inherited reliance on the formal narrative classicism that epitomized the structure of films preceding World War II did it begin to reach a philosophically mature or "postmodern" status, engaging the seemingly senseless confusion of life in the late industrial world. For all three thinkers, this process of transformation was led by filmmakers from the most powerful nations of the time, whose collective ideals and conceptions of the world had been shattered by the war. For Jameson in particular, the films that emerged signaled a new stage in the global, historical development of politics, economics, and thought-a state of affairs that, he frequently argued, the Third World of the 1970s did not experience in the same way. In this context, cinema, while seen as an unprecedented industrial/mechanical method of representation with a history that is in many ways autonomous from that of other arts, adhered nonetheless to a similar process of formal development, tracing a "microchronology" that "recapitulates something like a realism/modernism/ postmodernism trajectory at a more compressed tempo" (Jameson, 1992a, p. 156). The moment of realism, Jameson argues, marks the emergence of a new medium at a particular historical moment and thus represents a heady period of grappling with and establishing the fundamentals of an emergent technology of representation and its basic techniques and forms. This involves "the conquest of a kind of cultural, ideological, and narrative literacy by a new class or group" (p. 156). For cinema then, the industrial working class of the twentieth century is argued to have served as the proving ground on which realist form was defined. Following the condensed timeline set by Jameson and other theorists, high modernism soon emerged in the work of the cinematic avant-garde, although arguably while the classic/realist aesthetic was still being perfected. Following the war, this gave way to the "allusive 'cultural capital' of the postmodern, which 
ransacks all the preceding cultural moments for its new forms of 'cultural credit"' (pp. 156-157).

While Deleuze (1989) does not use the term postmodern to describe cinema following World War II, his analysis of the "time images" that emerged in the work of many filmmakers during and after the 1940s bears key similarities to Jameson's definition of a postmodern cinematic approach, particularly in terms of the thorough saturation and interpenetration of the on-screen present with various formalized traces and signs of the past. History, for Deleuze, appears and becomes sensible within distinct "regions" of the image. These, in their enduring copresence with the current state of affairs represented on screen, show that the past is not simply a vanishing series of events leading to the present but something that lingers, continuing to influence the contemporary in profound and often insidious ways. For Deleuze, to begin to recognize the ways in which the past is a living and active force in the present is to embark on a program of reading one's surrounds-or those included in a cinematic image-in a deeper and more potentially effective way. To do so, however, is never a simple matter and often involves a traumatic challenge to the limited, normative/presentist perspectives of characters and viewers alike.

The entirety of Orson Welles' Citizen Kane (1941), for example, consists of a highly detailed search-indeed something of a ransacking-for a deceptively forgettable detail in the past life of media magnate Charles Foster Kane. At issue is the word "Rosebud," uttered cryptically by Kane on his deathbed and hence taken as a potential key to understanding the muchpublicized fall from grace that preceded his demise. Circumstances thus lend Kane's otherwise random communiqué the appearance of a mysterious and powerful element of his past, one that it is feared may die along with him if not thoroughly investigated. A reporter is tasked with solving the puzzle, and the film embarks on a process of scouring the present for a piece of history that appears to have been shaping Kane's character from some unseen, deeply entrenched place. As Deleuze (1989) writes of Citizen Kane, "the investigator carries out soundings; each of the witnesses questioned will be equivalent to a slice of Kane's life, a circle or sheet of virtual past, a continuum. And each time the question is: is it in this continuum, is it in this sheet, that lies the thing ... called Rosebud?" (p. 105).

A clue to the meaning of the word is famously provided by Welles at the beginning of the film, but its connection to the mystery is only confirmed at the end: "Rosebud" is the moniker printed on a sled with which the fiveyear-old Kane is seen frolicking in the snow in an early flashback sequence. The scene occurs just before an event that alters the course of Kane's life, as an inheritance transforms him from an impoverished yet carefree child 
to an orphan effectively enslaved by the responsibilities and expectationsand later the sheer ridiculous possibilities-of great wealth. Significantly for the purposes of my analysis, the answer to the mystery of Rosebud is conveyed not with dialog but through the deep focus style that Deleuze argues to have been invented by Welles. In it, the image indeed appears to be divided into layers or sheets that represent different "regions" of the past; although these coexist simultaneously in memory without a particular order or rank, they are not necessarily given equal weight by consciousness. So it is as well in the flashback sequence where the layers are positioned to coincide on screen. Unlike a more straightforward flashback, the image in this case reaches beyond the awareness of the individual who is the source of the memories (here Kane's former caretaker and financial manager, who is recounting Kane's past to the reporter) and into regions of the past that have gained more importance in the remembrances of others.

The "sheet" that is essentially Kane's own recollection-his happier, poorer self with Rosebud-is hence positioned as a distinct yet equally focused background layer that is visible outside the window of the small boarding house where Kane's parents are busy renegotiating his future in the foreground. Lit as brightly as the characters in the foreground and further accentuated in contrast with the darker wall visible around the window, the young Kane can be seen and heard jumping and shouting unintelligibly in the snow, as if trying desperately to draw attention to his now-imperiled existence as a normal child. The goings-on in the foreground, however-as the focus of the more conscious elements of remembered past driving the flashback-continually work to suppress this alternate, resistive layer. As the deal for Kane's inheritance and move to the city comes to a close, his father thus absentmindedly walks over and shuts the window, temporarily blocking Kane from view and silencing his voice. Yet for all the distinctiveness and apparently unequal status assigned to each layer of the past, it is precisely in the extreme, almost forced appearance of depth and separability created by Welles' imagery that Deleuze locates an implicit, paradoxical sign that these visual/temporal regions can never truly be kept apart.

Like Jameson's argument for film's development as a "compressed microchronology" (1992a, p. 156) that hastily retraces the trajectories of earlier media, Deleuze sees Welles' innovative rendering of visual layers as a reiteration of a key "stage" in European painting, and in artists' mastery of depth perspective in particular:

It will be a novel change, and crucial, in the seventeenth century, when an element of a plane refers directly to an element of a different plane, when characters address each other directly from one plane to another, in an organization 
of the picture along the diagonal, or through a gap which thus privileges the background and brings it into immediate touch with the foreground. (p. 107, emphasis added)

In both seventeenth-century European imagery and in Citizen Kane, Deleuze (1989) argues, the result was thus not merely the illusion of depth but a forced union of visual layers cum regions of time: a "violent perspective which does even more to unite the near and the faraway" (p. 107). The deeper the appearance of the image in both its visual and temporal dimensions, the more the use of clear, straight lines to emphasize dimensionality simultaneously gives up its own trick. From a certain perspective, the boldness of the diagonal lines reveals flatness and compression, showing that all the "sheets" and sequences of the past contained in the image are in fact forced together and are as inseparable from each other as from images and events in the present.

In Jameson's (1992a, 1992b) understanding of postmodern cinema, the relationship between past and present functions in a similar way: the image is almost totally composed of references to the forms and modes of past media, which are rearranged and made to play out in the viewing, thinking present. For both Jameson and Deleuze then, what is "new" in postmodernism or in postwar time images is a far greater sense of the continuing effects of the past than of novelty and emergence, which are the discourse and feelings that shaped earlier "realist" or "movement" images. The closeness of the past in postmodernist cinema hence also overflows and challenges modernist claims to the freedom to produce the new through conscious experimentation and modification. In the postmodern or the "time" image, the past thus becomes both a catalyst for certain kinds of innovations and an inescapable force of sameness that puts a check on the headiness and drive for progression in previous cinematic modes. The more idealist modes of earlier films, with their emphasis on heroism and individual achievement, are thus attenuated by the emergence of a newer, deeper sense of reality, one that particularly reflects the unavoidable, often horrifyingly complex ethics of engagement during World War II.

\section{The Wrinkling of Time: \\ The "Coincidental" Postmodernity of Indonesian Screen Arts}

In attempting to understand a film like Bernafas dalam Lumpur (Djunaidy, 1970) in relation to Deleuze or Jameson's widely applied theories of postwar cinema, it is important not only to understand the evolution of film form in the West but also to have a sense of the specific paths of development of Indonesian politics, art, and cinema. In comparison to Deleuze's terms of progression, for example, Indonesian cinema has not, to my knowledge, 
passed through a moment in which deep focus style came into particular prominence or was notably popular with cineastes, audiences, or critics. ${ }^{4}$ This may have been due in part to the limitations in the equipment available to Indonesian crews in the 1950s and throughout much of the Sukarno and subsequent Suharto regimes (the key technical element of deep focus such as that practiced by Welles is large, expensive lighting setups that require a massive source of electricity). But outside of the problem of access to certain tools, a technique like deep focus might have a far less salient place in the historical-artistic "archives" drawn on by Indonesian cineastes.

For Jameson (1992a) and Deleuze (1989) a deep, layered image represents an important stage of development for Western cinema because, among other things, it shows that Western filmmakers have finally been disabused of their obsession with the novelty of motion pictures and have begun to look to the history of European painting for inspiration. If founding Indonesian directors like Usmar Ismail or Asrul Sani were also looking to earlier patterns and forms of artistic expression to inform their work, colonial influence aside, it stands to reason that they would not primarily have been following a chronology of "stages" driven by social, political, and economic developments in Europe. In fact, the problem of visual perspective and the purportedly shocking truth of its flatness had already been addressed in Indonesia long before the seventeenth century. ${ }^{6}$ Particularly as such flatness relates to the function of time, the formal innovations of wayang kulit (Javanese shadow play) would appear to be the most relevant local historical reference for a "postmodernist" cinematic approach.

The flattening and estrangement of on-screen space in order to accommodate an expansive sense of the dimensions of history, causality, and time lies at the very heart of wayang's approach to representation and its continuing engagement with history and the politics of the globalizing present. Its visuals, unlike those of classical European painters or Welles' cinema, have always eschewed realist representation in depth, and the sense of flattening is hence more direct: characters and elements representing disparate kingdoms, class backgrounds, and even centuries are literally pressed together in two dimensions on the backlit screen. The puppets' shadows are thus visible on the other side of the screen as projections. While there are ways to create a sense of depth or layering, as when the puppet is pulled back from the screen toward the light-source-normally a bright lantern-and the shadow-image of a particular character grows immense and its position is emphasized vis-à-vis others, there is little or no pretense to the use of point perspective or to the graphic/mimetic imitation of reality. As the actual puppet moves and is differentiated from its surrounds, it remains visibly connected via the screen. Its shadow, if often wavering and 
shifting in size and focus, always shares a space with the disparate actors, objects, and interests surrounding it. Because some of these elements represent past or future events and entities, as Deleuze (1989) puts it in the context of cinema, one might say that in wayang "the unbridled depth is of time and no longer of space" (p. 108). It is not clear, however if there was a "realist" precursor to wayang in Indonesian performing arts or screenbased media.

In wayang kulit the profound influence of other times and places on current narrative events is further underscored by the thick swathes of puppets that extend in tightly packed rows past the left and right borders of the screen. The rows represent entire historical/genetic lineages, the most ancient members of which are always within reach and available to be taken up and injected into the dramatic present by the dalang (puppet master). Bound by the lack of spatial dimensionality in the image, any single character or element is thus unable to escape its fate by simply moving or progressing to a moment in time that is shown to be separate and safe from the on-screen present or from the particular moments of the past that are visually carried along within any current event.

The "postmodern" spatiotemporal structure of wayang is most evident in the scenes known as gara-gara, which consist of immense, stormy conflicts where natural and geopolitical forces combine to sow widespread chaos. Borrowing from Madeline L'Engle's A Wrinkle in Time, René Lysloff (1993) argues that the temporality of gara-gara is akin to L'Engle's tesseract: it produces something like a temporal wrinkle in which "the space time continuum seems to fold up on itself, bringing together alternate times and places" (p. 49). Yet as in the political cinema of the twentieth century, the most crucial element of time in wayang is the present in which the "folding" takes place.

As in Welles' technique of flatteining the contemporary moment against a historical-political field of potentially epic proportions, in wayang, too, with the Ramayana or Mahabharata as vast narrative-historical backdrops, a key function of gara-gara is to disrupt and press the current time of performance and spectatorship against the "ancient" and ostensibly predetermined developments on screen. Here as well then, a sense of temporal regions as distinct arenas pressed into an inescapable intimacy is established. In the process, history and the present are imbued with the sense of a common underlying structure while also paradoxically producing a feeling of contingency and potential surprise-the looming proximity of an immeasurable historical totality is precisely what makes the current moment and what is to follow difficult to predict. The dramatic apprehension 
this creates, I would argue, is a big part of what continues to draw audiences to wayang performances so many centuries after the medium's advent.

Unlike most films, the open structure of wayang exhibition also allows spectators to glimpse the dalang behind the screen as he or she (although generally he) stages events and constructs the story. The audience is thus exposed to the mechanisms of pretense and forgery with which the images and sounds they consume are manufactured. Yet because the ability to see the dalang at work is also considered part and parcel of the "show," when viewers wander behind the screen to witness the puppet master's performance, the actual space and time of spectators is itself positioned as if it were engulfed within the constitutively open and ever-expanding narrative universe of wayang. This is especially strong during gara-gara, when there is a pause in the progression of narrative events and spectators are directly addressed by characters on screen. As Jan Mràzek (1999) and others argue, ${ }^{7}$ the dynamic tension within gara-gara is precisely based on this sudden appropriation of the "real" present of the audience, placing it into a narrative that has thus far been identified as occurring in a distant, mythical past. This coincidence of disparate times, spaces, and dramatic and historical realities is formally underscored by the entrance of a number of punakawan or clown-servant characters, who bridge and mediate between material and narrative worlds by calling out to viewers, in common parlance and as approximate social equals, unlike the lofty heroes who do not appear cognizant of the fact that they are performing and being watched. A.L. Becker (1995) describes the clowns as "wide awake men in a dreamworld" who "step among the heroes, demons and gods" (p. 39) and also among audience members, bringing the structures and intrigues of their narrative world to bear on a host of current sociopolitical issues and concerns.

As in the tentative steps we take toward Rosebud at Welles' behest, it is precisely the carefully staged "coincidences," bumbles, and trips of the punakawan that may point viewers in the direction of greater wisdom. As the clowns continually collide with the formal and social limits that define their all-inclusive world, they implicitly trace the presence of a broader, unseen "systemic cause" of the narrative events into which they draw the audience, and of the formal modes with which these events are expressed. One might also think of this invisible force in Raymond Williams' (1954, 1977) terms as a "structure of feeling" that links the techniques, modes, and genres of artistic expression in a particular place to the patterns of social and political development there. The clowns' role is thus not only to drive and creatively disrupt the story on screen but also to point to the presence of a historical politics of expression that joins and makes inseparable the visibly disparate spaces and temporalities of dalang, spectators, and puppets. The 
formal/performative reflection on the existence of such a systemic cause that Jameson and Deleuze saw in the "postmodern" Western cinematic responses to late capitalism is thus also operant in a medium whose origins lie in the antediluvian globalization of Hinduism and the political campaigns of precolonial Javanese rebels and kings.

\section{Language and "Epic" as Archive}

For Becker (1995), these aspects of wayang are structurally related to the enduring temporal and causal configuration of the Javanese language (Javanese has gone through many important changes and modifications in grammar and alphabet while retaining certain basic structural elements), into which the Mahabharata and the Ramayana have been translated, adapted, and endlessly written, recorded, and performed since their local inception as products of historical exchanges with India. Becker argues that the structure of time and causality in Javanese and wayang makes them highly distinct from typical linguistic and dramatic forms in Europe and other Indo-European speaking areas: "Clarity and coherence means to speakers of these [European] languages linear temporal/causal sequencing" (p. 33). Put another way, in English, for example, without a chronological sequence of cause and effect that clearly separates past, present, and future, the meaning of a sentence, paragraph, or entire story might easily appear jumbled, incoherent, or simply incorrect. For Becker, this ideal, basic patterning of expression is also often implied or assumed by speakers, writers, and consumers to reflect typical understandings of the broader structures of history and human reality. Clean, rationalized relationships between past, present and future are hence "taken as facts about the world rather than facts about language" (p. 33).

As in the structure of expression in wayang then, the structure of language engulfs historical reality, lending it a particular form and shaping the outlooks of its speakers. Unlike the engulfing function in wayang, however, the structural manipulation of time and human agency is kept carefully obscured in Western/Indo-European languages and classical dramatic forms. As Jacques Lacan (2005) argues, the function of this type of linguistic structure is to hide the fact that meaning, and thus knowledge, exists in the unconscious prior to its expression by the subject via language. In communication between subjects, the chronological organization of language appears to position the speaking or writing subject as an agent, as meaning is normally only revealed at the end of a sentence composed by the speaker/writer, and the listener/reader must wait to receive this knowledge until a grammatical subject is "completed" with a verb and a predicate. The 
appearance this creates is of the speaker as the source of knowledge and of information as generally new and produced in the present.

The allegedly untenable or traumatic truth that meaning usually preexists its production in the present-and thus is not new per se: it comes from the past-is therefore effectively hidden within a linguistic veil of human agency. Underneath this veil, wrote Lacan (2005), the unconscious contains the "truth about truth," a level of knowledge that is suppressed while meaning is conveyed through a language that proffers a "lack of truth about truth" (p. 737). For Jameson and Deleuze, both of whose work is profoundly influenced by Lacan, the postmodern era is one in which the "horrifying" truth about truth, that individual agency is for the most part an ideologically saturated myth, finally began to enter the awareness of individual subjects in a more thoroughgoing manner.

As Becker shows, however, in Javanese and in Indonesian, the national language, verbs and actions are not conjugated to express their tense: they do not precisely indicate when things happen, and thus it is not automatically clear if the information contained in a sentence or story is new or unprecedented per se. In speech and writing, and also in expressive media like wayang, time and historical cause are established not by the imposition of chronological ordering but through context and the juxtaposition of temporally disparate elements and events. ${ }^{8}$ The plots of shadow plays do at times also work to establish or at least reference the idea of regularized, sequential time and the ideals of linear causality and individual agency that are attached to it. But even then, as Becker explains, such moments are inevitably unsettled by a greater reliance on coincidence: events not obviously motivated within the presented narrative yet symbolically rich in terms of a larger framework of understanding that may be out of the characters' conscious grasp.

In the Mahabharata, for example, the life of Bhisma, one of the major characters, is continually beset by seemingly chance events that are shown to have a determining effect on his future and the entire narrative universe he inhabits. Despite his status as heir to the throne of Ngastina, due to complex circumstances beyond his control, the young Bhisma swears he will not occupy the seat of power and will never marry so as not to produce an offspring to whom he would pass his royal entitlement. Throughout the rest of the narrative, Bhisma's most important act is arguably that he stays true to his promise, inadvertently bringing about a conflict with Amba, a princess whose own complicated circumstances, including rejection by another king whom she loves, have led her to demand that Bhisma marry her. When he refuses her, she curses him, and he receives a vision and 
correctly predicts his own death in battle at the hands of another woman: the warrior Srikandi.

While the use of temporal markers like "before" or "as a young man" establishes the general order in which these events take place, the "ending," Bhisma's death, is positioned near the beginning of Bhisma's story, which is interwoven with many other strands of the Mahabharata's broader narrative. ${ }^{9}$ The non-chronological presentation thus de-emphasizes the novelty of his death and of the audience's knowledge thereof. If there is a potential for agency invoked here, it would seem to arise from a process of familiarization with the complex mixture of unpredictable events from which the narrative is composed, possibly revealing a pattern, if not a greater purpose behind them. Only then is it possible to "act," as, for example, the punakawan or dalang do, in a comparative meta-temporal manner, folding and pressing together narrative and historical pasts and presents in such a way as to indicate revealing points of coincidence between them.

As Becker (1995) points out, the word for "coincidence" in Javanese and Indonesian is kebetulan, which is based on the root word betul, meaning "true". In wayang, the sudden, chaotic moments of convergence between old and new and between linguistically, temporally, and socially dissimilar interests, while at times subverting literal comprehensibility, can thus also be said to represent the glimmer of a larger, symbolic truth about the story and its connections to the lived present, historical memory, and the formation of knowledge itself. For Becker and many others, in Java and elsewhere in Indonesia, the glimmer of coincidence is a persistent kernel in otherwise shifting structures of expression. As explained earlier, in theories of Western art and cinema, such a glimmer is more frequently identified as a potentially traumatic seed of historical transformation, which deconstructs and challenges classical and modern traditions (as well as the worldviews attached to them), heralding and driving the unprecedented onset of "postmodernity."

The enduring popularity of Javanese adaptations of the Mahabharata and the Ramayana demonstrates the flexibility and continuing marketability of the "ancient" and less chronologically determined outlook they represent. The adaptability of both texts also shed light on the problems raised by the frequent application of the term "epic" (as in "the Hindu epics" or the "Javanese Hindu epics") to these and other lengthy, complex, non-Western narratives. Understood as a European "genre that has not only long since completed its development, but one that is already antiquated ... with a hardened and no longer flexible skeleton" (Bakhtin, 1981, p. 3), epic is a poor fit for the Ramayana and the Mahabharata. As Meenakshi Mukherjee (2006) argues in regard to the origins of the two narratives, "epic in the 
context of India means neither 'primary epics' like the Iliad or the Odyssey, nor the secondary variety written by Virgil or Milton. In fact, there is no exact synonym for epic in Sanskrit-the language in which the Ramayana and the Mahabharata were originally composed" (p. 601).

While the Ramayana was created as part of the Indian genre of kavya or "narrative in verse," the Mahabharata, Mukherjee (2006) writes, is primarily associated with the style of "itihasa ('thus it happened' - what is now called history)" (p. 601). Because of the exhaustive and highly detailed nature of the Mahabharata-earlier versions were eight times the length of the Iliad and Odyssey put together-and due to its strong connection to the telling of history, its narrative universe functions not only as a vast and enduring source of entertainment but as a kind of archive-a collection of the expressions of power and desire that drive and constitute human actions, the depth of which can easily appear endless. While the Ramayana also offers an extensive compendium of moral codes, for Mukherjee it is the Mahabharata that more closely approaches something like a political reading room: "a vast storehouse of stories around the core narrative of a fratricidal battle in a royal clan abounding in tales of deceit, aberration, transgression, deviant morality, greed, treachery, and lust, thereby problematizing the relationship between statecraft and ethics" (p. 602). In India, even two thousand years after their inception, both texts thus continue to serve as important comparative sources for "alternative ideas of the nation" and as tools and weapons that are frequently employed "in currently raging ideological battles across the country" (p. 603).

The lasting influence of both texts and especially the potential to deploy the Mahabharata, as Mukherjee (2006) suggests, as a recognized basis for political intervention, lend them an aura of authority commensurate with that of an official archive. As Jacques Derrida (1998) reminds us, the term "archive" takes much of its force from the Greek arkheion, which denotes "the residence of the superior magistrates, the archons" (p. 2), to which official documents were brought and filed. The archons or "those who commanded" were not kings but derived their authority to create or express the law through their privileged access to the archives. Yet it is the documents themselves, argues Derrida, in which the law is grounded. It is therefore the documents, not the archons as agents, that "speak the law" (p. 2) in the eyes of the public and rulers alike. The archons serve as the documents' guardians and translators, keeping the powers they convey out of the reach of others who might produce alternate interpretations.

At first glance, this would seem to create the opposite effect in comparison to Lacan's understanding of the function of grammatical structures such as sentences: here, information must be seen as predating 
the expressions of the archons, whose agency is openly and inseparably bound to the files contained in the archive. Yet in Derrida's conception of the function of the archives, something is similarly concealed: the fact that the contents of archives are generally the result of a policy of collecting as much information of a particular type or types as possible, such as recordings of events or lists of important people or things or even just "books." Archives can thus rarely be said to contain any discernible messages or narratives in and of themselves. As the products of such a depersonalized impulse to gather and save information, V. H. Galbraith (1948) famously compared the contents of archives to "the secretions of an organism."

What is perhaps most closely guarded in many archives is that their contents, while positioned as the basis for, among other things, the production and exercise of law and order, are also the arbitrary results of a policy of gathering anything that fits into a set of categories that at some level are entirely "meaningless." The secret then is that the expressions of archons cannot necessarily be traced and located as such in the contents of archival documents, and thus carry a great potential for bias. This is why Derrida (1998) referred to archives as ghostly or spectral spaces, where the referent of most statements or expressions is "neither present nor absent 'in the flesh,' neither visible nor invisible" (p. 84). Searching there for a solid, sensible foundation for meaning or for collective understandings of an issue or event, one may suddenly feel as if one has entered a haunted hall of mirrors, chasing after "a trace always referring to another whose eyes can never be met" (p. 84).

As Mukherjee (2006) argues, texts like the Ramayana and the Mahabharata function as a vast storehouses for information relevant to public conceptions of ethics and statecraft. In this case, similar to Lacan's conception of grammatical structures that guard "the truth about truth," the collection contained in these texts is obscured by the deployment of narrative: the archival meta-function of the texts that Mukherjee pointed to is potentially hidden by their reception as complex and engrossing stories. The authenticity of these stories' form, moreover, is often closely guarded and hotly debated, subject to contesting claims of interpretive authority. Yet in the sheer extremity of the texts' length and number of variations, the Mahabharata and the Ramayana would seem already to be encouraging diligent fans and readers to become lost in their vastness, potentially uncovering the germs of ideas and events whose present manifestations are thereby lent a less original and more spectral appearance. In this sense the Mahabharata and the Ramayana bear out their distinction from the "hardened and no longer flexible skeleton" (Bakhtin, 1981, p. 3)-the rigid structural archon-of the European epics to which they are often carelessly 
compared. The Indian texts, it would appear, are the products of a different set of structural, temporal, and psychic relations between narrative and information.

In Indonesia, the local adaptations of the Mahabharata and the Ramayana continue to grow and shift with each performance, retelling, or rewriting. They have hence also retained a spectral relevance to current affairs and the potential to engulf the present moment within a seemingly infinite collection of conflicts, events, and narratives that connect and entangle the contemporary with the past. In a generally ghost-obsessed populace, I would argue that this constitutes an important part of the texts' continuing appeal and marketability.

With the constantintermedial rewriting and blending of the Mahabharata and the Ramayana with other narratives, including historical ones, and with the Javanese addition of gara-gara, the doors to these meta-narrative aspects are kept unlocked, almost as if issuing a challenge to adventurous readers or spectators. In my analysis, the collective unconscious realm that is conjured and brought further toward consciousness in the process can be thought of as an important archive-one without physical walls but inextricably bound to the place and people from whose exchanges its contents are secreted and for whom they are thus imbued with the weight of history. Through language and other modes of expression like wayang and cinema, this living assemblage is always in the process of entering the awareness of individuals. Its function is to indoctrinate but also, like an analyst who indoctrinates as well, to broaden perspectives on the workings of politics and the human mind, potentially unlocking the secrets of archons or other covert agents who operate in the same historical-epistemological locale.

\section{Cinema in the Early New Order: Learning to Breathe in the Bloodstained Mud of Indonesia Post 1965}

For Jameson (1992b), postmodern films like Three Days of the Condor are defined by their ability to draw viewers away from the face value of a present filled with "vivid miseries ... so as to think [them] together with [their] deeper, but non-visual systemic cause" (p. 2) - a totality not unlike an archive of past experiences and events that continually interacts with and shapes the contemporary. Drawing on its own embedded collection of historical events and on expressive forms and structures like wayang in which such events are "stored," Bernafas dalam Lumpur anticipates the mode of expression deployed by films like Three Days of the Condor, framing the acts of its characters within the epic machinations of Indonesian history and pressing them against the immense, secretive totality of contemporary political and 
economic cause and effect following the rise of dictator Suharto. Bernafas thus works to underscore, if not to fully unearth or visualize, the systemic, historical cause of the particular "vivid miseries" that it puts on display.

For Krishna Sen (1993), early New Order films like Bernafas indexed a major shift in Indonesia's popular cinematic discourse, leaving behind the focus on "register[ing] the transformative possibilities of human action" (p. 208) that she associates with the Sukarno years. In her view, Indonesian cinema thus appears to have passed through a process reminiscent of Jameson's (1992a) "realism/modernism/postmodernism trajectory". As she asserts, numerous classic films of the Sukarno era, such as the works of Usmar Ismail, Asrul Sani, ${ }^{5}$ and Nya Abbas Akup, do invite audiences to relive the transition from Dutch colonialism to independence, and hence these films do indeed frequently revolve around the idea of national transformation. Sen's claim that Sukarno era cinema is also generally obsessed with idealized human agency, however, is belied by the perspective of local critics, who often compared the approach of early national films to Italian neorealism, as well as to the more complex "lyrical realism" that followed it (Said, 1991, p. 53).

Despite postwar Italian filmmakers' adoption of the term realism, the neorealist movement is generally understood as a critical reaction to previous, more straightforwardly realist styles. For Deleuze (1989), neorealism was also among the key early genres in which previous obsessions with the transformative possibilities of human action were in fact finally thrown out the window in a thoroughgoing manner. Neo- and lyrical-realists in Italy are argued to have challenged both traditional realist and modernist ideals, paving the way for the global emergence of the postwar, postmodern "time image." If it was these films that emerged as the most apt comparison to the earliest examples of national cinema in Indonesia, ${ }^{10}$ we might need to rethink to some extent whether Sukarno-era cineastes were in fact so interested in the "transformative possibilities of human action" (Sen, 1993, p. 208).

A very different trend was especially strong in the controversial-yetaward-winning subgenre of films in the 1950s and early 1960s: a deep cinematic suspicion of positivism and of the role of individual heroes in changing their own and others' fates. Many such films focused on bekas pedjuang, veterans of the revolution against Dutch colonialism. Perhaps mirroring the experiences of early national filmmakers, almost all of whom fought in the war for independence, the pedjuang who appeared in films like Djajakusuma's 1952 Embun [Dew Drops], Ismail's 1954 Lewat djam Malam [After the Curfew], or Sani's 1961 Pagar Kawat Berduri [Barbed Wire Fence] were shown to have become thoroughly disillusioned by the propensity for 
violent conflict to exude not clarity and positive results, but an impenetrable moral confusion that blanketed not only the war, but the eagerly anticipated years of freedom and nation building that followed. Hence it is not individual heroism but precisely the dark, complex spectre of the former revolutionary as a "man who has given up" (Said, 1991, p. 55) that I would argue to have set the tone for cinema during the Sukarno era. Even popular comedies of the time like Usmar Ismail's Krisis [Crisis, 1953], Tamu Agung ([Exalted Guest, 1955], Tiga Dara [Three Girls, 1956], or Nya Abbas Akup's Tiga Buronan [Three Fugitives, 1957] adopted a critically deconstructive approach to the ideals of social and political action, following what Hanan (2009) argues to be a local tradition of political satire and thus keeping the national present folded against the epically wrinkled fabric of Indonesia's past.

The relatively early deployment in Indonesia of a cinematic approach similar to what is labelled postmodern in the West can thus also be said to challenge postmodernist theorists' assumptions that this kind of approach to representation is necessarily the result of a more or less clear, linear process of transformation. In Indonesia, even during the colonial era, art and film can be said to have constantly "ransacked" the local past for cultural credit, even while adopting emergent technologies, techniques, and ideas from around the globe. Without reference to narratives and tropes that were previously established as marketable in local public spheres, it would likely have been difficult to retain the native audiences who were the main consumers of films made in the Dutch East Indies. ${ }^{11}$

Bernafas dalam Lumpur, produced on the heels of the most significant local episode of mass violence after the war for independence-the rise of Suharto in 1965-66, which arguably fostered a far greater sense of collective disillusionment-is an apt example of how emergent local modes of expression ransack and are in turn ravaged by the accumulated effects of the past. By the time he made Bernafas, Djunaidy was a seasoned actor, director, and producer. What he put on screen, while not linked in a literal manner, inevitably points back into the thick of recent history, whence lurks the most salient cause of the present state of affairs in Indonesia: the murder of approximately 1,000,000 accused communists by Major General Suharto and the military in 1965-1966, which led to the displacement and discredit of the Left-leaning, anti-imperialist Sukarno, and to Suharto's implantation as Indonesia's second president. Likely due to the Suharto government's adoption of a policy of strict censorship of anything relating to the killings or directly critical of the state or its agents, these events are not explicitly referred to in Bernafas. Instead, viewers are presented with an unexplained yet pervasive culture of amorality - one in which, as Sen (1993) writes, evil 
has become so normalized that it is invisible as such, "dispersed through everyone... and every social institution" (p. 209).

In this context, many of those who survived the regime change appeared to almost inadvertently follow the military-cum-state's program of targeting and exploiting those whose positions had been weakened by the purges. In Bernafas, as in Three Days of the Condor (1975) or De Palma's Blow Out (1981), this state of affairs is dramatized through, among other things, the failures of the film's would-be hero to challenge or even fathom the forces actually shaping his and others' lives. A defining feature of all three films is thus the foregrounding of what seem to be coincidences and chance encounters, events that in fact function to outline the rigid, systemic boundaries governing individual agency. Hence, we become aware of the hidden machinations underlying the cultural/economic/political system operant in a certain area when characters' attempts to pursue moral ideals at odds with its interests cause them to bump into it, as their emergent desires to become individualistic, heroic "men of action" are repeatedly thwarted.

Bernafas dalam Lumpur, while stylistically distinct from Welles' early work or that of De Palma or Pollack, displays a strong grasp of how the aural, visual, and aesthetic components of cinema can work to compress and pressure the world conjured on screen, flattening disparate elements against each other, even as the "depth of time" within particular shots or sequences is expanded. As in other contemporary Indonesian films with similar themes, while the world appears to close in on would-be heroes, the perception of characters in lower or more vulnerable positions such as prostitutes often expands in proportion, ${ }^{12}$ providing the audience with at least two distinct perspectives on narrative events. ${ }^{13}$

In a more strictly visual, Wellesian sense, this is aptly demonstrated in one of the few forays into deep focus by Djunaidy and Akin, his cinematographer. Elsewhere, Bernafas generally employs editing techniques like shot-reverse-shot to establish the contiguity of various characters and elements. In this scene about an hour into the film, however, the distinct and opposing interests and views that the film has been working to establish are underscored and made to visually coincide in a single, dynamic shot.

In the scene leading to the shot, Budi (Rachmat Kartolo), an outwardly kind-hearted young man from an upper-class background, dozes off inside his parked Fiat as he waits for Mila (Suzanna) to collect her things from the nearby house that her pimp Rais (Farouk Afero) has provided for her. In a previous scene, Budi has finally convinced Mila, a successful midlevel prostitute and the film's central character, to give up her life as a sex worker and allow him, as he puts it, to "pull her out of the mud" in which she sees herself as terminally stuck. Mila had initially been doubtful of Budi's 
intentions as well as his potential as a savior; she seemed all too aware of the extreme delicacy and dexterity necessary to extricate herself from the rootlike clutches of Jakarta's sprawling socioeconomic underworlds. However, Budi has exploited Mila's only weakness: her daughter, who lives in a village outside the city with Mila's mother. "I love you . . . and your child," he tells her, finally putting Mila under the spell of Budi's idealism.

Although Budi offered to help Mila collect her things, she insisted it was unnecessary ("It's just one little suitcase"). Perhaps feeling that he has already prevailed and that rescuing her from her muddy locale is a fait accompli, Budi lets his guard down and she returns to the house alone. Seemingly hit with a bout of afternoon lethargy, he hunkers down in the reclining seat of his car and drifts off to sleep. With the scene inside the Fiat set, what follows is a montage sequence juxtaposing Budi's increasingly relaxed state with a rapidly escalating argument between Mila and Rais, who turns out to have been waiting for her in the house. Mila is Rais' highest earner and has also recently signed a contract to be sent to work in Hong Kong, a deal in which he has a large stake. Fearful of the consequences of losing her, Rais warns Mila she won't be able to "leave just like that." Fuelled, for the moment at least, by Budi's rhetoric of universal entitlement to love and individual rights, Mila is defiant:

"I'm a self-respecting human being!"

-“Since when?!"

"From now on. I'm no longer going to be your slave."

Unable to control her with verbal threats, Rais turns to violence, ripping Mila's clothes and striking her, causing her to fall, the side of her face colliding with a table. Leaving Mila to deal with the mess they've made of her house, Rais and with his two henchmen discover Budi, unarmed and unconscious, still snoozing contentedly in his car. The film then cuts to a long shot of Budi from inside the car, and as the three men approach to look in on him, they are framed by the two side windows opposite Budi, which divide the shot into two distinct regions or layers: one with the marginalized pimp and his colleagues deftly moving through their surrounds and the other with the ostensibly privileged Budi lying frozen, vulnerable, and unaware.

Budi and Rais have crossed paths before, when Budi refused to pay extra for staying with Mila longer than agreed-an encounter in which Budi also ended up unconcious, that time bleeding from wounds inflicted by the pimp's dagger. It was Mila who rushed him to the hospital and saved his life. This time, however, when one of his men raises a hand to strike Budi through the open car window, Rais foils the delivery of the blow and quietly indicates they should leave Budi undisturbed-they simply enjoy a muted laugh at his expense. Budi's calm demeanor and closed eyes betray his 
blindness to the realities of the situation-a lack of foresight that will lead him to sabotage his own goals far more effectively than Rais ever could. The pimp thus shrewdly reserves his energy for Mila, who actually possesses the power to hurt him if she chooses to break the alliance that has kept both of them afloat in the threacherous mud of dispossession churned up by the rise of the New Order.

It is precisely the truth of Mila's fragile yet potentially potent agency that Budi's various bouts of unconsciousness seem designed to prevent him from glimpsing. Sensing how little he sees or knows, Mila often handles Budi with extreme care, as if protecting his fragile ego. When he awakens in his car and finally decides to check on her, she instinctively keeps from him what he has thus far so conveniently missed: that his cavalier and manipulative bids for her heart are likely to get Mila killed. Asked why she's bleeding, she assures him she only tripped and hit her head.

\section{Awakening to the Sound of the New Order}

Although Mila continues to go through the motions of her plans with Budi, the fight with Rais appears to have broken her faith in Budi for good. A few days later, it is she who finds herself waiting in the car as Budi runs an errand in Kartika Plaza, an upscale Jakarta shopping center. ${ }^{14}$ Unbeknownst to him, some of his wealthy coworkers exit the mall as he enters. Noticing Budi from afar, they approach his car and take particular interest in Mila, who is sitting alone in the passenger seat. Rumors about her have already been circulating, and now they take the opportunity to look her over. "She is pretty," admits one. "But it's her skills he's after, she's had a lot of practice!" says another, causing the group to break into raucous laughter.

Unlike Budi, Mila remains alert to her interlocutors, absorbing the sharp words aimed in her direction. Djunaidy thus takes a different approach than in the previous scene, using a medium close up to focus on the intensity of Mila's expression as she processes the situation. Long shots of Budi's friends standing nearby are intercut with those of Mila. With each edit, the camera moves slightly closer to her, emphasizing the difficulty of the decision she is about to make. In a subtler, more insidious way than in Welles' "violent perspective," as the sound of their voices is made to coincide with her image, Mila is pressed up against the dictates of her privileged accusers, their words inscribing themselves in her reactions. Here, it is sound that works to flatten the disparate image-regions in the sequence against each other, signaling both their complex interconnectivity and the strong, instinctive opposition between the different socioeconomic strata and historical experiences that are associated with each. 
As Michel Chion (1994) writes of the function of sound in cinema more broadly, the aural presence of Budi's coworkers "spread[s]...like a gas" (p. 144) within and across images and splices, surrounding Mila with a poison that is all the more effective for its lack of direct, visual representability. "Poor Budi," they shoot again. "She must have put a spell on him. A guy from a good family fallen into the arms of a prostitute; he'll never escape." Their words and the logic behind them blend seamlessly with the noxious discourses of domination and victimization produced and sustained by the rise of the New Order-thinly veiled enunciations of ideological precepts that clog the atmosphere in Jakarta and elsewhere, preemptively poisoning anyone seeking to challenge the lot handed down to them by state-decreed "coincidences" of history or fate. Perhaps, then, the clouds of marital bliss with which Budi has promised to envelope Mila will merely suffocate her.

As the chatter continues, she finally opens the car door and walks away with a determined gait, doing her best to ignore the laughter and mock surprise that floats along after her. When Budi returns, his friends quickly disperse, once again leaving him blind to the cause of Mila's sudden disappearances, as if this were simply another coincidence. As he broods, Mila is whisked away by a car that stops, as if automatically, when she appears by the roadside nearby. Driven by a prospective john, it returns her to the thick of the urban mud from whence she came. Budi, as she will tearfully insist later, is "not like the others." But based on her increasingly clear perception of the limits of his agency and of what his obsessive love will likely beget, Mila has made an informed, if painful, choice: to disappear from the ideologically restricted spaces that Budi occupies, where she is seen by most as not fully human, and a "real" referent for her is barred from existence. For Budi, then, Mila becomes a spectral figure: a center of narrative and dramatic attention that paradoxically hovers on or outside the margins of the visible.

While Mila is ultimately unable to prevent the destruction wrought by Budi's efforts to save her, her disappearance at least succeeds in deferring the inevitable fate that his intervention has triggered. In the spirit of Derrida, furthermore, her more ghostly presence underscores the film's potential archival function. As the narrative drops its guard and clear-cut goals no longer appear logically sustainable, viewers' eyes are opened to the present as a place and time where agency is governed by shadowy figures "whose eyes can never be met." The longer Mila lives, the stronger our sense of the lack of conditions conducive to her existence in the flesh, a fact which may also serve as a reminder of the real spectres of recent history who have been relegated to haunt the archival margins of the New Order: those who have been arbitrarily defined as part of an inhuman, enemy force-the political 
Left-and whose mass suppression, killings, and arrests, if looked into more closely, would unravel the narratives deployed by the state to make sense of its rapid, violent rise to power.

\section{Breathing in the Archives: Reconstructing History Through Its Effects}

One of the most palpable effects of the politically-based violence carried out by Suharto and the military against the Indonesian communist party (PKI) in 1965-1966 was the drawing of an invisible line across much of the Indonesian archipelago, breaking the young nation into two simplistically defined opposing camps: left and right. In the political context of the time, the fear and socio-ideological power driving such discourses were especially virulent. Even the endlessly twisting metanarratives of the Mahabharata were at times paired down and deployed-emphasizing the final battle, where in wayang, the winners are always at screen right, with the losers on the left-in the service of such a reductive historical view. ${ }^{15}$ Those who had survived the transition to the New Order and remained in good standing were literally treading on the bodies of hundreds of thousands of accused communists, Leftists, and Sukarnoists-victims of the slaughter and mass arrests that brought Suharto to office. For privileged members of the upper class like Budi in Bernafas dalam Lumpur, there was all the more reason to tacitly or unconsciously delimit one's own view, avoiding even a quick glance into the disorienting, blood-soaked mud produced by the change of regime. To admit to seeing, or to begin to address, the twisted truths of history would not only potentially compromise the positions of those who had attached themselves to the authority of the new regime but would also almost certainly be perceived as a threat to the state's all-important work of covering its own tracks. This kind of seeing and speaking would thus risk suspicion, arrest, or an even worse fate. ${ }^{16}$

In mediums such as literature and film, however, a more nuanced and critically comparative perspective began to reformulate itself with surprising speed. ${ }^{17}$ In the case of Bernafas dalam Lumpur, it is true that there is no direct mention of or engagement with the government or the recent acts of the military. This would likely have simply ended in heavy censorship or an outright ban, and jeopardized the career of Djunaidy, the film's director, cowriter, and producer, who made it through the years of violence with his life and career intact. But given the climate of suppression and pervasive surveillance at the time, Bernafas could be considered bold in its depiction of life in the early Suharto years. As such, it helped inspire a number of subsequent films to critically re-imagine the changeover from the "old" to "new" order in terms of its effects on the lives and perspectives 
of people from the different sociopolitical regions of Indonesian society, with a particular emphasis on those in the most vulnerable positions.

The focus on Mila in Bernafas thus called on contemporary viewers to take a long look toward the archival margins of society, from which Budi's gaze was shown to be tacitly deflected. It is not made clear whether Mila's father, who is notably absent, was a victim of the New Order's purges or if her political background had been stained in the eyes of the powers that had arisen. However, in light of the reason that brought her to Jakarta in the first place-the selling of the rural plot of land which her husband had previously cultivated-it is quite clear that she is in a vulnerable position vis-à-vis the state's shifting economic development policies and that she is unlikely to benefit from other sociopolitical changes sweeping Indonesia following the rise of Suharto. After losing contact with her husband who has gone to the capital to find work, Mila decides to try to follow him to Jakarta. While the circumstances that bring Mila to Jakarta are thus beyond her control and what befalls her there at first seem like mere coincidences, the film works to demonstrate that what has happened is far from a case of random bad luck.

Early in the narrative, a long flashback sequence makes clear that as a woman entering the city alone and unprotected, and especially coming from a rural area, Mila is already marked in the eyes of most everyone she meets. The fact that Mila's husband has seemingly disappeared without a trace, and that she has come to Jakarta looking for him, are also apparent coincidences that fit a recognizable pattern. In the attacks on suspected leftists in 196566 , many husbands similarly vanished, and it was often unclear to their family members whether they were being held indefinitely somewhere, moved from prison to prison, or in the worst case, killed and buried in a mass grave. In many instances, the lack of clear information about missing spouses, relatives, or friends went unresolved for years, even decades. Often the last news, if there was any news at all, would be of prisoners taken to urban areas for processing. ${ }^{18}$ Someone like Mila, wandering the streets of Jakarta deparately seeking information about her missing husband, might thus easily be suspected to be a member of Indonesia's massive new political underclass.

Emergent government categories like "unclean environment," intended to tar those who were related to or in close contact with accused communists, helped create a sense that it was acceptable to act on quick, instinctual assumptions about the political affiliations of other citizens without any real evidence. As Bernafas demonstrates indirectly, the new state had opened the doors to a culture of victimization in which violence against a vague and purposely undefined Left-the insidious "enemy in your blanket" that 
it was claimed could suddenly appear anywhere-would almost certainly be free of repercussions. Djunaidy works to reinvest such wanton acts and the reductive thinking behind them with a sense of moral consequence by pushing viewers to inhabit Mila's complex and harrowed consciousness over much of the hour and a half they would spend watching the film. What is indicated as a more realistic source of evil in Bernafas, instead of some shadowy, mythical "communist," is the contemporary mindset of ordinary citizens who continually victimize Mila without provocation, as if driven by some unseen, internal trigger.

Perhaps in order to make a stronger point-and certainly also in the interest of sensationalism that would lead to more ticket sales-the level of violence and dehumanization presented by Djunaidy is extreme. As shown through a lengthy flashback that explains how Mila fell into prostitution, for example, within twelve hours of her arrival in Jakarta, she is taken advantage of and raped by three men. While the men come from distinct class backgrounds - two are poor pedicab drivers, another is the son of a wealthy businessman - they seem to share an ability to instantly identify Mila as the Other. Mila is not an easy victim, however, and fights hard to save herself from the men's advances, succeeding in preventing the father of her final rapist from repeating the actions of his son. Nonetheless, it becomes clear to her that something is terribly wrong, and there appears to be nowhere left for Mila to turn: everyone she has encountered in the city so far has seen her as a target, and although the fact that she is an attractive young woman is clearly shown to be an important motivator for her attackers, the relentless and totalizing nature of what occurs would seem to exclude any explanation based solely on gender.

Anticipating the "ransacking" of established forms and techniques that Jameson would label postmodern in American films of the mid 1970s, Djunaidy draws on the typical tropes of a number of different genres to imbue Mila's experiences with a causal depth that exceeds mere lust on the part of her attackers. The rape scenes, for example, often recall the camerawork, editing, and sudden piercing screams typical of horror films, underscoring the sense that something else is driving the men to these acts of violence. Music is also strategically mixed and matched: when Mila suddenly bumps into her husband at a busy roadside warung, or food stand, her initial joy and relief is punctuated by a few melodramatic notes from the soundtrack by composer Idris Sardi, as if conspiring to pull at our heartstrings on Mila's behalf. She soon discovers, however, that her husband is now married to the owner of the warung, who is presumabley supporting him. When the proprietress begins to push and hit Mila, he thus stands helplessly by; here, the score briefly modulates into an active, pulsating rhythm, miming the 
scene's dramatic tension. But both of these recognizable generic musical forays are quickly withdrawn. As it appears to finally dawn on Mila that, whether by history or fate, her life has been irreversibly changed without her knowledge or approval, the music shifts again. Mirroring her blank expression, the tune begins to meander, eluding tones or melodies that could be easily identified with any particular emotion, now effecting a Brechtian distanciation that paradoxically appears to bring us closer to what Mila is feeling. The cues that typically signal a certain genre or style are hence made to seem as unreliable as those that would otherwise anchor Mila's identity in a stable sense of her social and political position and rights.

As the woman who is now married to Mila's husband continues assaulting Mila, she repeats the words of the well-heeled man Mila recently succeeded in fighting off: "lonte?" ("whore"). A look of detached realization spreads across Mila's face, betraying a need to separate the shredded remains of her former self from the scene at hand. The camera lingers in a closeup as the subjectivity drains from her expression, then begins to waver and sway, as if appropriating Mila's perception and passing it along to the viewer. When she wanders off in a daze, the camera seems to unmoor itself from the ground, drifting inhumanly through the chaotic midst of heavily trafficked streets accompanied only by the sounds of the meandering, looping, synthesized jazz that now adorns the score. The resulting "POV" shot expresses something closer to the lack of a normalized, subjective point of seeing: precisely a view from the margins imposed by the New Order.

Not long after, Mila collapses by an open sewer where Rais has just finished relieving himself. Considering the chain of events that has just befallen her, this chance meeting begins to take on the appearance of yet another structurally fated coincidence. It was only with Rais' help, Mila later explains, that she was able to survive her transition to life in the city. But it was also Rais who led her "down into the mud," employing her as a prostitute, and making her aware that the words of her former attackers held a strange kind of truth. As a lonte outside of the structures of family and other Suhartoist social and political ideals, she has learned to perceive, negotiate, and "breathe" in the thick-and for our purposes, archivalurban sludge that flows beneath the surface of life in Jakarta, the heart of the nation.

\section{Lonte and the Power of Ideological Fury}

The choice of lonte as the adopted identity of Bernafas's main character is of course also no accident. As I have shown elsewhere (Yngvesson, 2014), prostitutes have played important symbolic and material roles in the history of Indonesia, particularly in the context of the nationalist movement. In 
addition to their work as spies and weapons smugglers during the struggle for independence against the Dutch (1945-1949), urban sex workers since at least the 1930s have frequently appeared as the subjects of well-known paintings and poems, and were the source of the rousing slogan on the ubiquitous nationalist poster "Bung, ayo bung!" ${ }^{19}$ After 1965, the established symbolic value of prostitutes and prostitution was again taken up and exploited, although this time in a more uniformly negative register as part of Suharto's campaign to reframe and legitimize the unspeakable atrocities committed by the military against the Left.

The term lonte and other words for prostitute like pelacur or perempuan jalang were most prominently deployed by the state against Gerwani, a popular progressive women's organization closely associated with the Left prior to 1965 (both the communist party [PKI] and Gerwani were banned by the government following the events of 1965-66). In widespread media campaigns concocted by the military in the early months and years of the New Order, Gerwani members were painted as licentious quasi-prostitutes who allegedly danced naked in front of several high-ranking military officers, torturing and castrating them before the officers were killed as part of an attempted "communist coup d'état" on 30 September 1965. These events were taken up as a foundation for official narratives explaining the rise of the New Order, once again indelibly etching prostitutes and prostitution into the minds of the public. In the state's version of the events, the killing of the officers was claimed to have been carefully planned and carried out by the PKI and Gerwani. Similar narratives were widely publicized by the military soon after, and these were used as justification for the elimination and arrest of hundreds of thousands of citizens accused of affiliation with the PKI, Gerwani, and other left-leaning organizations in the months that followed.

As Saskia Wieringa (2002) argues, the media's military-authorized reconstruction of the events, in which Gerwani was accused of practicing and organizing prostitution, whipped much of the public into a particularly vicious "ideological fury" (p. 291) due to the graphic descriptions of Gerwani members' emasculation of the generals (as Wieringa also points out, autopsies revealed they had simply been shot and were neither tortured nor castrated, but these reports were kept from the public). As a result of the widespread reports of Gerwani's alleged role in the generals' deaths, "the PKI became associated with disorder symbolized by women's perverse sexual behaviour. Society could only be saved from this chaos by a systematic cleansing of communism and the re-subordination of women" (p. 281). Drawing on eyewitness accounts of the mass slaughter of suspected communists in the following months, Wieringa argues that the killings of 
suspected communists, whether carried out by soldiers, hastily formed paramilitary groups, or other sympathetic organizations, often took on an explicitly gendered dimension. While men were still the primary targets of the violence of 1965-1966, women, simultaneously taken as powerful political actors and dangerous moral corruptors of the nation, were also specifically targeted, particularly if they were suspected of being members of the three million-strong Gerwani, leading to ubiquitous accounts of rape and sexual torture.

In this context, Bernafas dalam Lumpur and the many other prostitutecentered films released in the early to mid-1970s-Sen (1993) referred to this trend as the "prostitution genre"-could be seen both as reflecting the horrific tenor of then-recent events and as a response to the state's ubiquitous deployment of gendered narratives to discredit the targets of its mass killings. Building on the actress Suzanna's complex portrayal of Mila, Bernafas submerges viewers into a culture of extreme violence, impunity, and wanton hatred that coincides with the rise of the New Order. At the same time, the film works to re-humanize and build sympathy for those who, like Mila, were continually victimized by a combination of patriarchal desire and "ideological fury" against loosely defined enemies of state and society, a mixture that constitutes a cornerstone of Suhartoist discourse.

As both a spectral figure and the film's main point of audience identification, Mila draws viewers' attention to the geographic and psychic margins where traces of collectively suppressed memories, events, and associations lurk. Simultaneously, she pushes viewers to confront the injustices inherent in the status quo and to consider alternate historical narratives leading not to a just, legitimate state, but to the present condition in which many Indonesians like her survive by "breathing in mud." While the effect is akin to the violent, revisionist perspective of Citizen Kane, it is important to note that in the end of that film, Kane's archive of collected documents and belongings, including the answer to the question of Rosebud, is burned, signaling a return to a normative present from which the deeds and memories of the past are largely banished. In comparison, the method and politics of Bernafas are closer to those of wayang, where temporal wrinkles are used to address the audience in a more direct manner, engulfing them in the expansionist time and space of performance. The present is hence never sanctified or left unperturbed, as layers of "ancient" politics and intrigue are revealed to coincide with contemporary reality, exerting a continual, and indeed inexorable influence.

In Bernafas, the cumulative effect of these operations is that Mila's exiled subjectivity, relegated by the state to the discredited "evils" of the past and marked for incineration, is forcibly pressed back into the officially 
limited spheres of public expression and commerce that serve as ongoing sources of collective identity. Budi's lack of awareness of the deeper causes of Mila's problems, on the other hand, serves as a foil and an example of exactly what needs to be changed-what can be called his Suhartoist political unconscious, which prevents him from seeing the root cause of her problems as the very same "ethics" that are the foundation of his own privilege and power. ${ }^{20}$ Budi's continual confrontations with the spectre of Mila's "goodness" thus provoke him to the point of obsession. As the film implies, this is because who he feels she is at a human level contradicts who or what he knows she is at an ideological level.

On the night he gets stabbed, his semiconscious state allows his "real" perspective to come to the fore: seeing Mila holding vigil by his side at the hospital, he viciously insults her, calling her a whore and ordering her to leave. When he awakens the next morning, however, and the nurse explains that it was in fact Mila who saved his life, his mission to find her and "set things right" takes on an air of great importance. The film's source of drama is thus not simply in Mila's and Budi's on-again, off-again romance and the potential for her ostensible redemption. More compelling are Budi's repeatedly missed encounters with a painful truth: that by virtue of his position and the historical baggage it carries, his efforts on Mila's behalf will only be able to hurt her, further derailing her life and placing her in real danger. Here, as Sen (1994) has argued about the 1970s Indonesian "prostitution genre" more broadly, the political depths made visible by Mila's dualistic identity and the fact that she continues to breathe and act outside the social and economic spheres of marriage and monogamy "signifies a crisis for the symbolic world" (p. 144). It is this crisis then, rather than his conscious desires, that Budi is driven to address, feverishly bandaging then unconsciouly reopening the wounds inflicted on his ideologically blinkered worldview by his encounters with Mila.

Diverging from Sen's analysis, however, I would argue that Mila's inevitable death is not a sign of passive acquiescence to the amoral and rigidly patriarchal order of the Suharto era. Instead, her passing literally constitutes a bloodcurdling scream in the face of the state's claims to justice and legitimacy. Accordingly, when a doctor confirms Mila's death in the film's final scene, her grief-stricken mother, who has been summoned by Budi at Mila's request, begins to utter her name uncontrollably. As the older woman falls to her knees and embraces her daughter's lifeless body, the word "Mila," which has for much of the film already signified an absent, vanishing person who has only now been physically destroyed, is transformed into a horrific, unrecognizable shriek. Functioning precisely like a "gas" with a "quasi-autonomous existence with relation to the visual field" (Chion, 1994, 
p. 150), the mother's vocalization spreads within and across the images in the sequence, which consists of a series of close ups on the reactions of those standing around Mila's body. The uncomfortably intense wailing continues throughout, and as the mother is slowly led out of the room, the sequence returns to Budi, whose look-as always magnetically drawn to Mila, who now stares back through closed, lifeless eyes-betrays the pain of loss along with a glimmer of realization.

As an ending to the narrative, the scene indeed fails, or perhaps refuses, to offer anything terribly surprising. But on the level of form, more is clearly being conveyed, and it is here that we might locate the film's final attempt at intervention. As in the warung scene above, the music slows and melodramatic accents are added, and the combination of this with the sound of Mila's mother's eerie, unrelenting screams would appear to be aimed at catalyzing a certain kind of reaction in spectators: forcing, or "jerking" tears from viewers, or creating lumps in their throats. As Linda Williams has argued, in these kinds of moments characterized by excessive emotional display, the bodies of viewers are incited to an "almost involuntary mimicry" of the corporeal and affective states of characters on screen (1991, p. 4). It is precisely the activation of this semi-conscious penchant for bodily imitation in audiences that Williams identifies as the hallmark, and main selling point, of the so-called "body genres": pornography, horror, and melodrama. Far beyond base imitation or a simple source of cheap thrills, however, for Williams, the powerful effects these genres can produce in viewers carry strong social and political undertones. As such, moments of excessive arousal (whether emotional, sexual, or fearful depending on the genre) function to create a pause in the flow of on-screen events, hence challenging the primacy of linear narrative and opening a space for viewers to sympathetically release pent up emotions, while at the same time potentially letting go of their reliance on "a fixed position with respect to... objects and events" (p. 10).

In Bernafas dalam lumpur, viewers have already been provided with a number of different positions and ways to view the film's interpretation of life in the early New Order, including the historically marginal outlooks of Mila and Rais. The final scene thus merely confirms what the audience has likely come to see as inevitable. Yet in pushing viewers to closely observe the human effects of something already known or deeply felt to be true, but not yet spoken, the film engages in what Williams terms an attempt to "address persistent problems in our culture...[and] in our very identities" (p. 9). As part of the complex, embodied processes triggered by melodrama, she writes, "we cry...not just because the characters do, but at the precise moment when desire is finally recognized as futile" (p. 11) —an idea Bernafas 
has repeatedly deployed against the false Suhartoist ideology driving Budi's attempts at heroism.

In the end, as Budi himself finally seems to get the message, the excessive tone and quality of the accompanying scream (which seems to "speak" for everyone in the room, including Budi) underscores the surplus of pathos generated by Mila's death and the web of unseen causes surrounding it, sublimating the feelings they elicit in characters while at the same time returning viewers to the human and generic horrors evoked elsewhere in the film. The scene thus appears to be working overtime-in a way appropriate to the ransacking, "postmodern" mode of gara-gara-to breach the diegetic veil imposed by the screen and reach out to then-contemporary Indonesian viewers, many of whose recent experiences may have also caused them to know, or to have seen or heard "too much." As if tears or lumps in throats were materializations of the unrepresentable-yet-ever-present terrors of history that the film as archive unearths, the final scene works to unhinge, at least for a moment, the conscious distinctions of class, party politics, and even gender, positioning viewers to feel the full, combined force of the various "coincidences" that have resulted in the end of Mila's life.

Roughly a decade later, De Palma's conspiratorial American drama Blow Out (1981), which Jameson called a "postmodern sequel" (1992b, p. 142) to Michelangelo Antonioni's 1966 Blow Up, ends on an uncannily similar note. In De Palma's film, a soundman (John Travolta) in search of the perfect scream to punctuate a shower-stabbing scene in a cheap slasher film stumbles onto a mystery: the killing of a popular, progressive governor and presidential hopeful has been covered up, apparently with the collusion of the police and other authorities. In appropriate postmodern form, the soundman's attempts to solve the mystery behind the plot and to save the woman, who is also "coincidentally" caught up in its machinations, end in abject failure. While fighting desperately to stop the murder of the woman, who turns out to already be dead, the would-be hero takes the life of the murderer, eliminating any chance of finding or bringing to justice the shadowy figures behind the plot. His attempts to ensnare the murderer with a wireless mic hidden on the woman's body thus yield only one thing: a recording of the bloodcurdling scream of the victim of an invisible yet pervasive and horribly real web of political intrigue, in which both victim and failed hero have found themselves ensnared.

Like Djunaidy, De Palma ends his film on the sound of a woman's scream. In this case, De Palma deploys sound more as an ironic display of the characters' utter powerlessness, as the recording of the woman's actual 
scream is ultimately inserted into the slasher film on which the distraught soundman had been working. For Jameson (1992b), this fatalistic final twist also functions to "transfer the visible clue to realm of sound," signaling the "unconscious, Utopian longing to be awakened from the spell of images" (p. 142) that have come to dominate modern landscapes of power and the experience of subjects. In both films, I would argue, there is a sense that truth can no longer be represented in the visible terms of the dominant order, wherein things are constantly arranged, rearranged, and edited so as to appear equitable and normal. The scream and the soundwaves that carry it, unbounded as they are by the definite contours of the visible image, thus give emotional impact and materiality to that which is barred-by both the direct actions of the state and the ideological blinders broadly inflicted by citizens on themselves-from being otherwise explained or depicted. This is perhaps particularly true in the case of Bernafas dalam Lumpur, where the conspiracies it stumbles upon issue from an all-toopresent and pervasive threat-the Suharto government and the military under its control-that links the diegetic space of the film to the historical dangers of Indonesia during the New Order. Mila also frequently screams at members of the upper class whom she feels are exploiting her, since the alarm-like, public nature of the sound clearly makes them uneasy and often temporarily puts a stop to their advances. In both films, however, the use of sound constitutes a last resort that lacks the positive potential of achieving justice or concrete results. Following the trail of utterances that function as clues, viewers are drawn instead to take an expanded sensory view from within the unfathomable mire of contemporary politics.

If there is a glimmer of hope in Djunaidy's film that is not present in De Palma's, it is probably because the tangled "postmodern" approach to representation in Bernafas is not necessarily new or historically unprecedented in Indonesia. Rather, the basic ingredients of Djunaidy's method are akin to the "specific ethical approach to reality" (1977, p. 137) that Mikhail Bakhtin argues to recur throughout literary history due to its "capacity to insinuate itself into large genres" (p. 99). The structure and style of Bernafas can thus be seen as both shaped by the historical developments of the mid 1960s, and inscribed in a vast and temporally undefined "archive." The collection of events, chronicles and memories the film opens onto, however, is not housed in a government building or library, but is constituted across uncountable iterations of "epic" historical narratives that continue to reappear in the present, pressing against contemporary reality and challenging its sanctity and sense of separation from the spectres and stories of the past. 
As in Western conspiracy films of the time, emergent technogeographies of commerce and power in Bernafas dalam Lumpur signal the workings of shadowy local/transnational political economic networks that are implicitly positioned as the sources of the pervasive-yet-unseen "evil" with which characters constantly collide. Yet in Bernafas, the return to the centrality of social outsiders - and particularly to the historical prominence of women in this role-offers a modicum of subversive potential that is absent in the ditsy female victims and failed heroes of Blow Out or other postmodern American films of its ilk. Imbued with a robust, if "negative" value in the eyes of the state, like the other central figures that define the Indonesian prostitution genre, Mila is the closest thing on screen to an agent, and carries the potential not only to breathe, but to observe, to read and to think within the muddiest structural depths to which the state has relegated her.

Dramatizing the split between individual suffering and the collective symbolic power embedded in Mila's position as a prostitute, Djunaedy produces a horrifyingly full sense of the archival structure of time (Deleuze, 1989), as well as of political, historical causality (Jameson, 1992a, 1992b). The present is thus saturated with both the unseen events of recent history and, crucially, a sense that this state of affairs is simultaneously unacceptable and in some sense deeply normal: whether or not some terrible event lurks only a few years in the past, one is always beset by layers of history that must be contended with in order to negotiate the present in a meaningful manner. Not unlike the deceptively lowly punakawan or clown servants of wayang, Mila, a prostitute who has fallen into the vilest depths of servitude under a new king, is charged with the task of leveling and connecting with the audience, potentially restimulating their blinkered sensitivity to the politics of history and memory. As a concluding voiceover assures viewers, Mila is gone and will never return. But there are "thousands and thousands" of others like her, it reminds or perhaps warns us. "Who, then," it asks, "is at fault? Is it men, is it women?" These queries are simply followed by the word "sekian" ("that's all") superimposed on the screen, leaving the question of causality in the minds, hands, and gut-feelings of the audience. 


\section{References}

Abdi, Z. (1969-70). Bernafas dalam lumpur (serialized novel). In Varia (p. 601-624).

Adisubrata, J. (Producer), \& Noer, A.C. (Director). (1977). Suci sang primadona [Suci the prima donna] [Motion picture]. Jakarta, Indonesia: PT Gramedia Film.

Bakhtin, M. M. (1973). Problems of Dostoyevsky's poetics. Ann Arbor, MI: Ardis.

Bakhtin, M. M. (1981). Epic and novel. In M. Holquist (Ed.), The dialogic imagination: Four essays by M. M. Bakhtin (pp. 3-41). Austin, TX: University of Texas Press.

Betz, M. (2010). Beyond Europe: On parametric transcendence. In R. Galt \& K. Shoonover (Eds.), Global art cinema: New theories and histories (pp. 31-47). New York, NY: Oxford University Press.

Biran, M. Y. (2009). Sejarah film 1900-1950: Bikin film di Jawa [The History of film 1900-1950: Making films in Java]. Jakarta, Indonesia: Komunitas Bamboo.

Carey, P. (2008). The power of prophecy: Prince Dipanagara and the end of an old order in Java, 1785-1855. Leiden, The Netherlands: KITLV Press.

Chion, M. (1994). Audio-vision: Sound on screen. New York, NY: Columbia University Press.

Clark, M. (2006). Pipit Rochijat's subversive mythologies. Asian Folklore Studies 65(1), 21-44.

Deleuze, G. (1989). Cinema 2: The time-image. Minneapolis, MN: University of Minnesota Press.

Derrida, J. (1998). Archive fever: A Freudian impression. (E. Prenowitz, Trans.). Chicago, IL: University of Chicago Press.

Djunaedy, T. (Producer \& Director). (1970). Bernafas dalam lumpur [Breathing in mud] [Motion picture]. Jakarta, Indonesia: PT Sarinande Films.

Elsaesser, T. (2005). European cinema: Face to face with Hollywood. Amsterdam, The Netherlands: Amsterdam University Press.

Gabriel, T. H. (1982). Third Cinema in the third world. Ann Arbor, MI: UMI Research Press.

Galbraith, V.H. (1948). Studies in the public records. London, UK:Thomas Nelson.

Hanan, D. (2009). A tradition of political allegory and political satire in Indonesian cinema. In Y. Michalik \& L. Coppens (Eds.), Asian hot shots: Indonesian cinema (pp. 14-46). Marburg, Germany: Schüren.

Hanan, D., \& Koesasi, B. (2013). Betawi moderen: Songs and films of Benyamin S from Jakarta in the 1970s. Indonesia 91, 35-76.

Hanan, D. (2017). Cultural specificity in Indonesian film: Diversity in unity. Melbourne, Australia: Palgrave Macmillan.

Heider, K. (1991). Indonesian cinema: National culture on screen. Honolulu, HI: University of Hawaii Press. Heryanto, A. (1999). Where communism never dies: Violence, trauma and narration in the last Cold War capitalist authoritarian state. International Journal of Cultural Studies (2), 147-177.

Holt, C. (1967). Art in Indonesia: Continuities and change. Ithaca, NY: Cornell University Press.

Ismail, U. (Producer \& Director). (1953). Krisis [Crisis] [Motion picture]. Jakarta, Indonesia: Perfini.

Ismail, U. (Producer \& Director). (1955). Tamu agung [Exalted guest] [Motion picture]. Jakarta, Indonesia: Perfini.

Ismail, U. (Producer \& Director). (1956). Tiga dara [Three girls] [Motion picture]. Jakarta, Indonesia: Perfini. Ismail, U. (1983). Usmar Ismail mengupas film [Usmar Ismail unwraps film]. J. E. Siahaan (Ed.). Jakarta, Indonesia: Sinar Agape Press.

Ismail, U. (Producer), \& Akup, N. A. (Director). (1957). Tiga buronan [Three fugitives] [Motion picture]. Jakarta, Indonesia: Perfini. 
Ismail, U., \& Malik, D. (Producers), \& Ismail, U. (Director). (1954). Lewat djam malam [After the curfew] [Motion picture]. Jakarta, Indonesia: Perfini/Persari.

Jameson, F. (1992a). Signatures of the visible. New Yourk, NY: Routledge

Jameson, F. (1992b). The geopolitical aesthetic: Cinema and space in the world system. Blomington, IN: Indiana University Press.

Kovács, A. B. (2007). Screening modernism: European art cinema 1950-1980. Chicago, IL: University of Chicago Press.

Krauss, W. (2005). Raden Saleh's interpretation of the arrest of Diponegoro: An example of Indonesian 'proto-nationalist' modernism. Arkipel, 69(1), 259-294.

Larasati, R. D. (2013). The dance that makes you vanish: Cultural reconstruction in post genocide Indonesia. Minneapolis, MN: University of Minnesota Press.

Litto, G. (Producer), \& De Palma, B. (Director). (1981). Blow out [Motion picture]. Hollywood, CA: Filmways Pictures.

Lysloff, R. T. A. (1993). A wrinkle in time:The shadow puppet theater of Banyumas. Asian Theater Journal, 10(1), 49-80.

Masak T. P. (2016). Sinema pada masa Soekarno [Cinema in the Soekarno era]. Jakarta, Indonesia: Fakultas Film dan Televisi, Institut Kesenian Jakarta.

Mrázek, J. (1999). Javanese wayang kulit in times of comedy: Clown scenes, innovation, and the performance's being in the present world, part one. Indonesia (68), 38-128.

Mukherjee, M. (2006). Epic and novel in India. In Franco Moretti (Ed.), The novel volume 1: History, geography and culture (pp. 596-631). Princeton, NJ: Princeton University Press.

Mutia T. (Producer), \& Pelamonia, N. (Director). (1973). Anjing-anjing geladak [Mongrels] [Motion picture]. Jakarta, Indonesia: PT Mutia Film.

Nugroho, G., \& Herlina, D. S. (2015). The crisis and paradox of Indonesian film (1900-2012). Yogyakarta, Indonesia: Provincial Office for Culture of Yogyakarta Province.

Pakula, A. J. (Producer \& Director). (1974). Parallax view [Motion picture]. Hollywood, CA: Paramount Pictures.

Pausacker, H. (2004). Presidents as punakawan: Portrayal of national leaders as clown-servants in Central Javanese wayang. Journal of Southeast Asian Studies 35(2), 213-233.

Putra, G. (2017, 15 November). Hilang dan mati pasca 1965 [Disappeared and dead after 1965]. Harian IndoProgress. Retrieved from https://indoprogress.com/2017/11/hilang-dan-mati-pasca-65/.

Resink, G. J. (1975). From the old Mahabharata to the new Ramayana orders. Bijdragen tot de Taal-, Landen Volkenkunde 131(2/3), 214-235.

Robinson, G. (1995). The dark side of paradise: Political violence in Bali. Ithaca, NY: Cornell University Press.

Roosa, J., Ratih, A., \& Farid, H. (Eds.). Tahun yang tak pernah berakhir: Memahami pengalaman korban 1965 [The year that never ended: Understanding the experience of victims of 1965]. Jakarta, Indonesia: ELSAM/ISSI.

Roosa, J. (2006). Pretext for mass murder: The September 30th movement and Suharto's coup d'état in Indonesia. Madison, WI: University of Wisconsin Press.

Roosa, J., \& Nevins, J. (2005, 6 November). The mass killings in Indonesia. Counterpunch. Retrieved from http://www.counterpunch.org/roosa11052005.html

Said, S. (1991). Shadows on the silver screen: A social history of Indonesian film. Jakarta, Indonesia: The Lontar Foundation. 
Sani, A. (Producer \& Director). (1961). Pagar kawat berduri [Barbed wire fence] [Motion picture]. Jakarta, Indonesia: Kedjora Film.

Sani, A. (1997). Surat-surat kepercayaan [Letters of faith]. A. Rosidi, (Ed.). Jakarta, Indonesia: Pustaka Jaya.

Sen, K. (1993). Politics of melodrama in Indonesian cinema. In W. Dissanayake (Ed.), Melodrama and Asian cinema (pp. 205-217). Cambridge, UK: Cambridge University Press.

Sen, K. (1994). Indonesian cinema: Framing the New Order. London, UK: Zed Books.

Schneider, S. (Producer), \& Pollack, S. (Director). (1975). Three days of the condor [Motion picture]. Hollywood, CA: Paramount Pictures.

Suprabto, D. (Producer), \& Shahab, A. (Director). (1973). Bumi makin panas [The Earth is getting hotter] [Motion picture]. Jakarta, Indonesia: PT Tidar Jaya Film.

Suryosumanto (Producer), \& Dajajkusumo, D. (Director). (1952). Embun [Dew drops] [Motion picture]. Jakarta, Indonesia: Perfini.

van Heeren, K. (2012). Contemporary Indonesian film: spirits of reform and ghosts from the past. Leiden, The Netherlands: KITLV Press.

Wardaya, B. T. (2006). Bung Karno menggugat: Dari marhaen, CIA, pembantaian massal '65 hingga G $30 \mathrm{~S}$ [Bung Karno charges: from the working class, the CIA, the mass killings of ' 65 to $\mathrm{G} 30 \mathrm{~S}$ ]. Yogyakarta, Indonesia: Galang Press.

Welles, O. (Producer \& Director). (1941). Citizen Kane [Motion picture]. Hollywood, CA: RKO Radio Pictures. Wieringa, S. (2002). Sexual politics in Indonesia. England: Palgrave Macmillan.

Williams, L. (1991). Film bodies: Gender, genre, and excess. Film Quarterly 44(4). 2-13.

Williams, R. (1954). Film and the dramatic tradition. In Williams, R. \& Orrom, M. (Eds.), Preface to film (pp. 1-56). London, UK: Film Drama Limited.

Williams, R. (1977). Marxism and literature. New York, NY: Oxford University Press.

Yngvesson, D. (2014). The Earth is getting hotter: urban apocalypse and outside women's collectives in Bumi makin panas. Plaridel 11(2), 53-84.

Žižek, S. (1991). Looking awry: An introduction to Lacan through popular culture. Boston, MA: MIT Press.

\section{Notes}

1 See, for example, D. Hanan and B. Koesasi's "Betawi Moderen:Songs and Films of Benyamin S from Jakarta in the 1970s" (2013) in Indonesia 91,35-76.

2 For a more in-depth analysis of the emergence of the popular and melodramatic "prostitution genre" in Indonesia in the early 1970s, see Sen's "Politics of Melodrama in Indonesian Cinema" (1993) in Melodrama and Asian Cinema (pp. 205-217) and Indonesian Cinema: Framing the New Order (pp. 131157).

3 See also, for example, Betz's "Beyond Europe: On Parametric Transcendence" (2010) in Global Art Cinema: New Theories and Histories (pp. 31-47); Kovács's Screening Modernism: European Art Cinema 19501980 (2007); Elsaesser's European Cinema: Face to Face with Hollywood (2005); or Gabriel's Third Cinema in the Third World (1982).

4 A survey of films from the 1950s to the 1990s, while turning up occasional scenes in deep focus, reveals no regular patterns or trends in the deployment of deep focus and/or staging in depth. In the growing list of monographs studying the history of Indonesian cinema, I was unable to locate a single specific reference to deep focus, staging in depth, or other relevant terms. See: Said's Shadows on the Silver Screen: A Social History of Indonesian Film (1991); Heider's Indonesian Cinema: National Culture on 
Screen (1991); Sen's Indonesian Cinema: Framing the New Order (1994); Nugroho \& Herlina's The Crisis and Paradox of Indonesian Film (1900-2012) (2015); van Heeren's Contemporary Indonesian Film: Spirits of Reform and Ghosts from the Past (2012); Masak's Sinema pada masa Soekarno (Cinema in the Soekarno era) (2016); and Hanan's Cultural Specificity in Indonesian Film: Diversity in Unity (2017).

5 Both Ismail and Sani argued vehemently in writing against the wholesale adoption of the Hollywood form in Indonesian cinema, which Ismail felt would make it, among other things, difficult for average Indonesians to follow local films (1983, p.181). Sani opined that the adoption of the Hollywood form would sever the links between local audiences and the images on screen, simultaneously raising the spectre of domestic films as "merely an imitation" (1997, p. 303).

6 In comparison to the revolutionary shift associated with the appearance of linear perspective and the resulting rise of mimetic naturalism in European art, the history of Indonesian painting appears generally less obsessed with the visual expression of depth. As Holt (1967) recounts, Europeans who witnessed a painting from the court of the East Javanese Majapahit empire in 1511 described the style of rendering people, animals, and other objects as "so natural that it could not have been better" ( $p$. 191). Raden Saleh, who studied in Europe over three decades in the mid-19th century and used depth perspective in his work, is generally known as the first "modern" Javanese/Indonesian painter (Krauss, 2005; Carey, 2008, pp. 698-699). Yet as Holt points out, when Saleh returned to Indonesia, although he was often sought out by Sultans and other wealthy patrons, he never founded a school to pass on what he learned and failed to produce any direct protégés who might carry on the styles he developed during his travels in Europe, Africa, and elsewhere (p. 192).

Sudjojono, one of Indonesia's most influential nationalist-era modern painters, agitated for young artists to turn their gaze toward Europe, among other places. But in so doing, he urged them to break with their "tourist-like sphere" and "become a large Garuda" —an important figure in the Ramayana"with strong wings who can carry you up to the blue sky ... where you will perceive and absorb the beauty of the world ... created by the Lord" (qtd. in Holt, p. 196). In this vein, Sudjojono, like Affandi, Basuki Abdullah, Agus Djaja, and other famous artists of the time, often drew on and combined myriad global influences in an effort to create and refine a modern Indonesian style (one which has remained in constant flux and is thus difficult to define), but never appeared overly concerned with the faithfulness of its proportions or realist/naturalist representation in depth. From my own years of observation in Indonesia, it is clear that the unabashedly flat, 'misshapen' nature of wayang images has remained a continual source of inspiration, among many others, that was taken up not only by early modern painters like Sudjojono or Affandi, but has also been adapted by contemporary artists like Heri Dono and Samuel Indratma. Flatness should thus be seen as a constant presence in the history of Indonesian art, one that has generally enveloped and distorted the "Western" influence of naturalist perspective.

7 Along with Lysloff (1993), see also Mrazek's "Javanese Wayang Kulit in Times of Comedy Part 1" (1999) in Indonesia 68; Clark's "Pipit Rochijat's Subversive Mythologies" (2006) in Asian Folklore Studies 65(1); and Pausacker's "Presidents as Punakawan: Portrayal of National Leaders as Clown-Servants in Central Javanese Wayang" (2004) in Journal of Southeast Asian Studies 35(2).

8 For example, in the Indonesian sentence "Aku kemarin jalan ke sini" ("Yesterday I walked here"), the verb jalan (in this case, "to go"/"to walk") has no conjugation that indicates time or tense. A direct translation would be something like "Yesterday I am walking here" or "Yesterday I walk here." Time is thus not inherent in verbs in Indonesian, and it is established by positioning the timeless/tenseless verb against a separate temporal marker that indicates the past: in this case,"yesterday." Furthermore, in Central and East Java and likely elsewhere, terms like "yesterday" or"tomorrow" are not as clearly defined 
as they are in English, with "yesterday" in particular often indicating moments or events that occurred several days or even weeks or months in the past. This is less the case, I discovered, in Jakarta, where my own use of an open-ended, central Javanese besok [tomorrow] to set a meeting time with a Jakartan colleague (who immediately appeared surprised) was "translated" by a friend who had lived in both central Java (in Yogyakarta) and Jakarta:"That's a Yogyakarta 'yesterday," he interjected with a smile, "It doesn't mean you have to meet the day after today."The tenseless nature of verbs, however, is the same throughout Indonesia.)

9 See, for example, Riantiarno's Mahabarata Jawa [The Javanese Mahabharata] (2016).

10 It should be noted that the main points of comparison between Sukarno-era films in Indonesia and Italian films of the preceding two decades are precisely the critical attitude toward human agency, as well as a tendency to shoot on location and mix professional and non-professional actors (Said, 1991, pp. 53-55). Beyond this, I would argue that the similarities between Italian and Indonesian films are far less marked. Indonesian filmmakers of the time were certainly aware of Italian neorealism and other globally renowned movements and styles, but they generally mixed influences from a variety of sources with local ideas, techniques, and tropes, creating a hybrid style aimed to engage with local audiences and with discourses of expression developed in local public spheres.

11 See Said (1991, pp. 13-30) and Biran (2009, pp. 8-26, 144-182).

12 In films like Nico Pelamonia's Anjing-anjing Geladak (Mongrels, 1972), Ali Shahab's Bumi Makin Panas (The Earth is Getting Hotter, 1973), and Arifin C Noer's Suci sang Primadona (Suci the prima donna, 1977), male protagonists generally fail to fully grasp the pervasive nature of the problems against which they struggle and end up failing to achieve their goals. The perspective of female characters who have fallen into prostitution, however, often provides a source of greater wisdom based on a view from inside the political economic system that has trapped them. On-screen prostitutes, whose critical words and actions also generally proved impervious to censors' scissors, quickly emerged as a central element of early New Order cinema, drawing a stark line of distinction from the majority of Sukarno-era filmic protagonists, who were generally men and/or middle class women.

13 In a related way, Hanan $(2017$, p. 134) uses the concept of double vision/seeing double to describe how Indonesian films openly display the variety of global influences they've absorbed while at the same time showing the audience a perspective that is distinctly Indonesian.

14 A centerpiece of Jakarta's development under the New Order, Kartika Plaza was renovated and launched as the Hotel Kartika Chandra in 1971 in a ceremony presided over by Suharto. It was later on to house the city's largest movie theater.

15 As Resink (1975) shows, before and after the events of 1965-1966, wayang and the Mahabharata in particular were frequently used as a method of speaking comparatively/metaphorically about political tensions and the resultant killings.

16 My understanding and analysis of the historical events of 1965-1966 is based on a general knowledge formed through years of interest, research and discussion, as well as from several published accounts, which provide a larger grid of facts and figures: Robinson (1995); Heryanto (1999); Wieringa (2002); Roosa, Ratih and Farid (2004); Roosa and Nevins (2005); Roosa (2006); Wardaya (2006); Larasati (2013); and Dwyer and Santikarma (forthcoming), among others. Another important factor in the formation of my perspective was my intensive, six-year participation as cinematographer and collaborator in the making of the film 40 Years of Silence: An Indonesian Tragedy (Lemelson, 2008). This allowed me to listen and speak to numerous survivors of 1965 , as well as to current Indonesian activists, archivists, and historians working to bring more critical public attention to the killings. Continual discussions and 
collaboration over the years with Degung Santikarma and Leslie Dwyer (who have a forthcoming book on 1965 in Bali), Hilmar Farid, John Roosa, Ayu Ratih, Alit Ambara, Baskara T. Wardaya and many others who study and concern themselves with the history of 1965-1966 and its aftermath have been incredibly important to expanding my understanding of, among other things, the ways in which the killings were carried out and their lasting effect on the lives of Indonesians on all sides of the conflict. My friends and colleagues at Taman 65 and Taman Baca Kesiman in Denpasar have also provided years of teaching and inspiration.

17 As I have shown elsewhere (Yngvesson, 2014), this was the case with many of the prostitutecentered Indonesian films that emerged in the early 1970s. These, in turn were based on or partially inspired by an earlier wave of what became known as "pocket bedroom literature": essentially pulp fiction dealing with the sordid experiences of contemporary urban Indonesians-and especially with prostitutes, hostesses, or the cheating wives of wealthy men-featuring several semi-explicit sex scenes as a de rigueur element of each story. The books were published serially in popular magazines or as stand-alone novels, and often as both. This was the case with Bernafas dalam Lumpur, which was penned as a novel by Zainal Abdi, and first published serially over 23 weeks between late 1969 and early 1970 in the magazine Varia, where its subsequent development into a film and a standalone novel was also advertised. The novel, however, is narrated by Budi, and thus does not achieve the "double vision" effect I've argued for in the film, which pushes viewers to inhabit both Budi's and Mila's perspectivesespecially Mila's.

18 On accused communists taken to urban areas for often lengthy periods of processing, see, for example:Hasworo's Penangkapan dan Pembunuhan di Jawa Tengah Setelah G-30-S [Arrests and Killings in Central Java after G-30-S] (2004); Razif's Romusha dan Pembangunan: Sumbangan Tahanan Politik untuk Rezim Soeharto [Forced Labor and Development:The Contribution of Political Prisoners to the Soeharto Regime] (2004); both in Roosa \& Farid's Tahun Yang tak Pernah Berakhir: Memahami Pengalaman Korban 1965 [The Year that Never Ended: Understanding the Experience of Victims of 1965]. Public writings about relatives or loved ones who disappeared and/or were killed in 1965-1966 began in 1998 after the fall of Suharto and continue to be produced on a regular basis. See, for example, Gde Putra's recent online piece "Hilang dan Mati pasca 1965" [Disappeared and Dead after 1965] (2017).

19 Using the typical egalitarian nationalist appellation "Bung" (Sukarno, for example, was and is commonly known as "Bung Karno"), the slogan roughly translates to "Brother, let's go brother!" The poster's image shows a man breaking a chain with which his hands are shackled while holding the Indonesian flag. The tagline was supplied by poet Chairil Anwar, who reportedly took it from the typical calls of Jakarta prostitutes.

20 To be fair, by the end of the film, Budi appears to be far more genuine in his feelings for Mila and may have been taken by many viewers as a "nice guy." But it is nonetheless clear that whatever ethical depth he has developed in the process of getting to know Mila is still an anomaly in Indonesian society. His actions therefore stand as the trigger, if not properly the cause, of Mila's death.

DAY YNGVESSON is a filmmaker and Assistant Professor of cinema and cultural studies at the University of Nottingham, Malaysia Campus. Using extensive archival and ethnographic research on globalization and political mass media in Indonesia, his forthcoming book challenges basic scholarly assumptions about the role of Hollywood and US imperialism in the development of non-Western cinemas. He is currently also finishing post-production on the experimental narrative feature Banyak Ayam, Banyak Rejeki (Many Chickens, Lots of Luck), co-directed and produced with Indonesian filmmaker Koes Yuliadi. Dag has published scholarly articles in Jumpcut, Indonesia and the Malay World, International Journal of Indonesian Studies, Plaridel, and others. (Corresponding author:yngve007@umn.edu) 